\title{
Heavy Metals in a High Arctic Fiord and Their Introduction with the Wastewater: A Case Study of Adventfjorden-Longyearbyen System, Svalbard
}

\author{
Agnieszka Kalinowska ${ }^{1, *}$, Małgorzata Szopińska ${ }^{1}$, Stanisław Chmiel ${ }^{2}$, Magdalena Kończak ${ }^{3} \mathbb{D}_{\text {, }}$ \\ Żaneta Polkowska ${ }^{4}\left(\mathbb{D}\right.$, Wojciech Artichowicz ${ }^{5}{ }^{(D}$, Katarzyna Jankowska ${ }^{1}$, Aga Nowak ${ }^{6}{ }^{(\mathbb{C}}$ and \\ Aneta Luczkiewicz ${ }^{1}$ (D) \\ 1 Department of Water and Wastewater Technology, Faculty of Civil and Environmental Engineering, Gdansk \\ University of Technology, 11/12 Narutowicza St., 80-233 Gdańsk, Poland; malszopi@pg.edu.pl (M.S.); \\ kjank@pg.edu.pl (K.J.); ansob@pg.edu.pl (A.Ł.) \\ 2 Department of Hydrology and Climatology, Faculty of Earth Sciences and Spatial Management, Maria \\ Curie-Skłodowska University, Krasnicka 2d Ave, 20-718 Lublin, Poland; \\ stanislaw.chmiel@poczta.umcs.lublin.pl \\ 3 Institute of Earth and Environmental Sciences, Faculty of Earth Sciences and Spatial Management, Maria \\ Curie-Skłodowska University in Lublin, Kraśnicka 2d Ave., Lublin 20-718, Poland; \\ magdalena.konczak@poczta.umcs.lublin.pl \\ 4 Department of Analytical Chemistry, Faculty of Chemistry, Gdańsk University of Technology, 11/12 \\ Narutowicza St., 80-233 Gdańsk, Poland; zanpolko@pg.edu.pl \\ 5 Department of Hydraulic Engineering, Faculty of Civil and Environmental Engineering, Gdansk University \\ of Technology, 11/12 Narutowicza St., 80-233 Gdańsk, Poland; wojartic@pg.edu.pl \\ 6 Department of Arctic Geology, University Centre in Svalbard, P.O. Box 156 N-9171 Longyearbyen, Norway; \\ aga.nowak@unis.no \\ * Correspondence: agnieszka.kalinowska@pg.edu.pl
}

Received: 5 February 2020; Accepted: 10 March 2020; Published: 12 March 2020 updates

\begin{abstract}
Longyearbyen is the largest settlement on Svalbard archipelago, with 2400 permanent residents and approximately 150,000 tourists visiting every year. The city annually releases approximately $285,000 \mathrm{~m}^{3}$ of untreated wastewater to the nearby Adventfjorden. To date, the environmental impact of this continuous input has been studied mainly regarding the sediments and benthic fauna in the fiord. Here, we present results from a study of raw wastewater entering Adventfjorden as well as heavy metals concentrations in the water column within the fjord itself. Two surveys were carried out in summer and autumn season 2018, to establish physical and chemical properties of water at various locations. Trace elements (V, Cr, Mn, Fe, Co, Ni, Cu, Zn, Hg, As, Cd, Pb, $\mathrm{U})$, total suspended solids (TSS) and total organic carbon (TOC) were measured. Our results show that Longyearbyen's raw wastewater introduces low concentrations of heavy metals to the fiord, but due to the growing number of inhabitants and tourists, it should be monitored to avoid degradation of Adventfjorden ecosystem
\end{abstract}

Keywords: High Arctic marine environment; wastewater discharge; heavy metals; ICP-MS; water pollution in the Arctic

\section{Introduction}

Svalbard archipelago is located in the High Arctic between $76.50-80.80^{\circ} \mathrm{N}$ and $10-34^{\circ} \mathrm{E}$ [1]. Despite its large area, the density of human population is very low (circa 0.04 person $/ \mathrm{km}^{2}$ ). This is because the majority of the population is concentrated in two major towns in the middle of the Spitsbergen island, Longyearbyen and Barentsburg, with a few small satellite research centers along the west 
coast. Both Longyearbyen and Barentsburg were established as mining towns in the beginning of the 19th century-therefore, throughout the years, coal mining left a distinct anthropogenic impact on the neighboring environment. Even though today, mining activity on Spitsbergen have significantly decreased (coal production dropped from over 4 million tons in 2007 to around 1 million tons in 2015) [2] and has been largely replaced by the ever-growing tourism industry, interest in pollutants pathways (via air, water and ground) and their fate in the Arctic environment is still rising. For example, in Longyearbyen, which is the administrative centre and the largest settlement of Svalbard, the wastewater is collected and directed untreated to the nearby Adventfjorden. Therefore, the wastewater discharge can be regarded as an important source of contaminants, such as nitrogen, phosphorus, organic matter, as well as human-related bacteria. Untreated wastewater may also contain heavy metals, which not only can have a deteriorating effect on the food web, but also may undergo bioaccumulation and biomagnification starting at the bottom of the food chain, with the ice algae or phytoplankton [3]. Furthermore, heavy metals also act as a stress factors, inducing, e.g., plasmid-related resistance against heavy metals among bacterial communities [1,4-6] and/or inhibiting microbiological processes [7].

Despite the above, the concentrations of heavy metals in wastewater in polar regions as well as their fate in marine environment have been investigated in only a few studies of marine sediments in Antarctica [8-10]. This lack of comprehensive research is partially due to the complexity/multitude of heavy metal sources that contribute to their concentrations in the High Arctic. Allochthonous sources include long-range atmospheric transport, volcanic eruptions or even wildfires [11-14], while autochthonous emission centers are commonly associated with coal mining and acid mine drainage, coal burning, road and air traffic as well as the energy sector [13]. Despite the scientific interest in heavy metals in the Arctic environment, to date, research has been focused mainly on soil [12,13], lake sediments [12,15], snow and glacier ice [12,16-18] as well as plants [19], fish and other animals [12,20-24].

In domestic wastewater, the household sources of heavy metals can be: laundry detergents and other personal care products, medicines, food, kitchen utensils and piping, but also tap water (Table 1). It is of special concern in Arctic areas; knowing the effects of anthropogenic pollution is a pressing matter since the population of Longyearbyen is continuously growing: from 25 people in 1906 up to 2400 inhabitants in 2019. Similarly, the number of tourists has doubled over the past 10 years, and in 2018 , it reached about 150,000 visitors per year [2]. Increasing activity in this area is directly connected to rising untreated wastewater release to the fiord each year.

Therefore, here, we present a coupled wastewater-fjord study of trace elements that was performed in the vicinity of Longyearbyen. The focus was given to the concentration of heavy metals in the wastewater as well as their seasonal and spatial distribution in the wastewater receiver-the Adventfjorden. 
Table 1. Typical sources of heavy metals in the domestic wastewater.

\begin{tabular}{|c|c|c|c|c|c|c|c|c|c|c|c|c|}
\hline $\begin{array}{c}\text { Domestic Sources of Heavy Metals in } \\
\text { Wastewater }\end{array}$ & $\mathrm{Cu}$ & $\mathrm{Zn}$ & $\mathrm{Pb}$ & $\mathrm{Cr}$ & $\mathrm{Ni}$ & $\mathrm{Cd}$ & $\mathrm{Hg}$ & Mn & $\mathrm{Fe}$ & Co & As & Reference \\
\hline $\begin{array}{c}\text { Household contribution to heavy metals } \\
\text { content in the typical municipal } \\
\text { wastewater }\end{array}$ & $27-100 \%$ & $30-46 \%$ & $0.9-15 \%$ & $2.4-15 \%$ & $9-61 \%$ & $20-60 \%$ & & $8 \%$ & $9 \%$ & & $21 \%$ & [25-29] \\
\hline Plumbing & $\checkmark$ & $\checkmark$ & $\checkmark$ & $\checkmark$ & $\checkmark$ & & & & & & & {$[25-27,30,31]$} \\
\hline Laundry detergents & $\checkmark$ & $\checkmark$ & $\checkmark$ & $\checkmark$ & $\checkmark$ & $\checkmark$ & $\checkmark$ & & & & $\checkmark$ & {$[26,27,31-34]$} \\
\hline Tap water & $\checkmark$ & $\checkmark$ & $\checkmark$ & $\checkmark$ & $\checkmark$ & $\checkmark$ & & $\checkmark$ & $\checkmark$ & $\checkmark$ & $\checkmark$ & {$[26,27,31,35-37]$} \\
\hline Kitchen utensils & & & $\checkmark$ & $\checkmark$ & $\checkmark$ & $\checkmark$ & & & & & $\checkmark$ & {$[25-27,38-44]$} \\
\hline Food & $\checkmark$ & $\checkmark$ & $\checkmark$ & $\checkmark$ & $\checkmark$ & $\checkmark$ & $\checkmark$ & $\checkmark$ & & & $\checkmark$ & {$[26,37,45]$} \\
\hline $\begin{array}{c}\text { Cosmetics (PCP-personal care } \\
\text { products): toothpaste, deodorant, } \\
\text { shampoo }\end{array}$ & & $\checkmark$ & & $\checkmark$ & & & & & & & $\checkmark$ & [26] \\
\hline Medicines & & & & & & & & & & & $\checkmark$ & [25] \\
\hline Feces & & & & & $\checkmark$ & & & $\checkmark$ & & & & {$[29,46-48]$} \\
\hline Amalgam & $\checkmark$ & $\checkmark$ & & & & & $\checkmark$ & & & & & [26] \\
\hline Artist paint & & & & & & $\checkmark$ & & & & & & [26] \\
\hline
\end{tabular}




\section{Materials and Methods}

\subsection{Study Area}

The study was conducted in the central part of West Spitsbergen island (Svalbard archipelago) in the vicinity of the largest settlement on the island, Longyearbyen (Figure 1), which discharges untreated wastewater (about 285,000 $\mathrm{m}^{3}$ /year) to the nearby Adventfjorden. Adventfjorden is a part of the biggest fjord on the west coast of Spitsbergen, Isfjorden. Its wide and deep mouth facilitates the water exchange with the central part of Isfjorden due to tidal pumping and wind-driven surface currents [49].

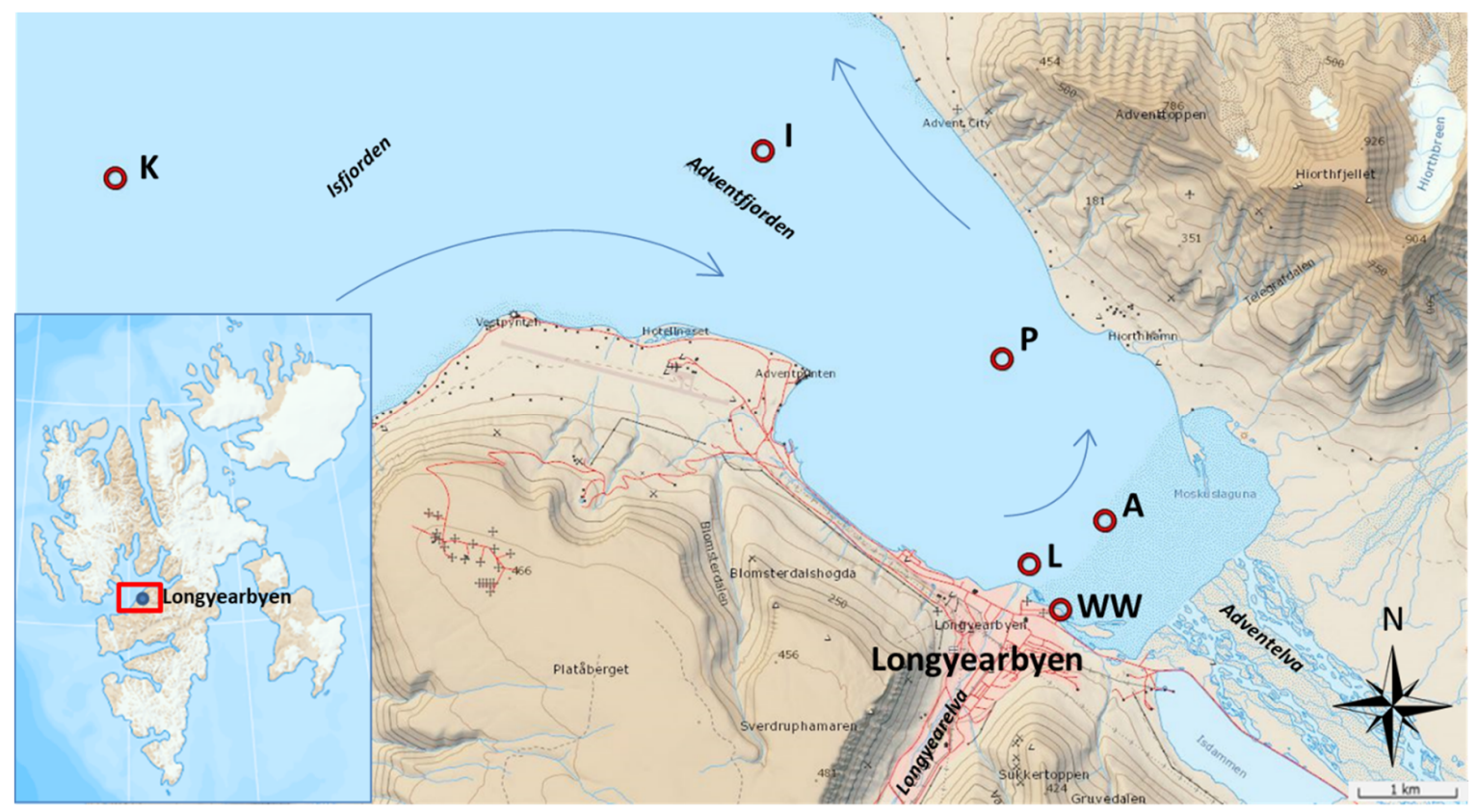

Figure 1. Location of the study in Adventfjorden, Isfjorden. The circles represent sampling points ( $\mathrm{K}=$ Karlskrona depth, reference point in Isfjorden; I = IsA station, reference point in Adventfjorden; $\mathrm{P}=$ wastewater pipe outlet to Adventfjorden, $\mathrm{A}=$ Adventelva outlet to Adventfjorden; $\mathrm{L}=$ Longyearelva outlet to Adventfjorden; WW= raw wastewater pumping station). The arrows represent dominant water current in Adventfjorden (modified from toposvalbard.no).

The largest contributors of freshwater into Adventfjorden are two, predominantly glacier-fed rivers: Adventelva and Longyearelva. Thus, they discharge large amount of freshwater (between 0.4 and $0.8 \mathrm{~m} /$ year $/ \mathrm{km}^{2}$, Nowak pers. comm) and suspended solids to the fiord (up to $1 \mathrm{~g} / \mathrm{L}$ in the melting season, mostly silt) [50,51]. Rivers can be also enriched in trace elements due to the presence of mining sites around Longyearbyen. They reach the maximum flow rate in the summer months, which significantly influences the physicochemical conditions in the internal part of the fiord (near river mouth-points L and A), while in autumn, their inflow ceases.

\subsection{Sampling}

Sampling points in Adventfjorden (Figure 1) were selected to reflect the inflow of wastewater to the fiord (sampling point $\mathrm{P}$ ) and the impact of two glacial rivers: Adventelva and Longyearelva (sampling points: A and L, respectively). In addition, two reference points were chosen to include dominant water current in Adventfjorden (Figure 1): station K (Karlskrona depth) located in the central part of Isfjorden, and station I, located inside Adventfjorden. Station K was assumed not to be impacted by the wastewater release, while station I could receive some of the pollution due to the water circulation in the fiord. Water samples in Adventfjorden were collected with a $10 \mathrm{~L}$ Niskin bottle at 
the surface $(0-1 \mathrm{~m})$ and bottom ( 5-10 $\mathrm{m}$ above sea bed) of the water column. To minimize the risk of contamination, samples were collected using nitrile gloves and bottles were rinsed three times with sampled water and then filled completely without air bubbles. Simultaneously, untreated wastewater was collected prior discharge to the receiver-from the last pumping station on the sewer system (sampling point WW, Figure 1). All the samples were kept frozen until further analysis. Samples were collected twice: in summer (July) and in autumn (October) 2018. Preceding sampling, the average daily temperatures varied around $5-10{ }^{\circ} \mathrm{C}$ in July and from $-12{ }^{\circ} \mathrm{C}$ to $5{ }^{\circ} \mathrm{C}$ in October. Precipitation did not exceed $0.4 \mathrm{~mm} /$ week prior to both of the sampling campaigns.

\subsection{Sample Analysis}

Total organic carbon (TOC) concentration was determined by a TOC-VCSH/CSN Analyser (SHIMADZU, Japan) using the catalytic combustion method with non-dispersive infrared detection (NDIR). Total suspended solids (TSS) were determined in duplicates by the membrane filtration method according to the Standard Methods [52]. The concentrations of metals: arsenic (As), cadmium (Cd), chromium $(\mathrm{Cr})$, cobalt $(\mathrm{Co})$, copper $(\mathrm{Cu})$, iron $(\mathrm{Fe})$, lead $(\mathrm{Pb})$, manganese $(\mathrm{Mn})$, nickel $(\mathrm{Ni})$, uranium $(\mathrm{U})$, vanadium $(\mathrm{V})$ and zinc $(\mathrm{Zn})$ in water and wastewater samples were determined by inductively coupled plasma mass spectrometry, Thermo XSERIES 2 ICP-MS (Thermo Fischer Scientific, Germany). The certified reference material EnviroMAT Ground Water (Low ES-L-2 and High ES-H-2) was used to validate the method. Trace element concentration CVs of the obtained triplicate results ranged from $0.5 \%$ to $3.0 \%$. Measurement range (MR), limit of detection (LOD) and limit of quantification (LOQ) are specified in Table 2.

Table 2. Analytical techniques employed to determine the analytes, together with selected validation parameters characterizing the analytical methods used.

\begin{tabular}{cccccc}
\hline Analyte/Parameter & Measurement Instrumentation & MR & LOD & LOQ & Unit \\
\hline $\mathrm{Cd}$ & Inductively Coupled Plasma Mass & $0.01-500$ & 0.01 & 0.03 & \\
$\mathrm{Co}$ & Spectrometer & $0.01-500$ & 0.01 & 0.03 & $\mathrm{\mu g} \mathrm{L}^{-1}$ \\
$\mathrm{~V}, \mathrm{Cr}, \mathrm{Mn}, \mathrm{Ni}, \mathrm{Cu}, \mathrm{Zn}, \mathrm{As}, \mathrm{Pb}, \mathrm{U}$ & Thermo XSERIES 2 ICP-MS & $0.10-500$ & 0.10 & 0.30 & \\
$\mathrm{Fe}$ & (Thermo Fischer Scientific) & $0.15-500$ & 0.15 & 0.45 & \\
Total Organic Carbon (TOC) & Total Organic Carbon Analyzer & $0.03-200$ & 0.03 & 0.10 & $\mathrm{mg} \mathrm{L}^{-1}$ \\
& TOC-V CSH (Shimadzu) & & & & \\
\hline
\end{tabular}

MR-measurement range; LOD—limit of detection; LOQ_limit of quantification.

\subsection{Data Analysis}

To detect pair-wise relationships among the metals, salinity, TOC and TSS concentration in the investigated water samples, Pearson's correlation coefficients (r) were calculated using Excel 2010. Statistical significance of correlation coefficients was assessed at a significance level of $p<0.05$. The statistical significance of correlations was verified using the Student's $t$-test.

\section{Results}

\subsection{Heavy Metals Concentrations in the Wastewater and Adventfjorden}

Wastewater generated in Longyearbyen contained higher concentrations of all heavy metals than the recipient, with the exception of $U$ and $\mathrm{Cd}$ (Table 3). The highest concentrations were noted in the case of iron $(226 \pm 79 \mu \mathrm{g} / \mathrm{L})$ and manganese $(176 \pm 62 \mu \mathrm{g} / \mathrm{L})$ and the lowest were in case of $\mathrm{Pb}$ $(1.12 \pm 0.53 \mu \mathrm{g} / \mathrm{L}), \mathrm{U}(0.11 \pm 0.02 \mu \mathrm{g} / \mathrm{L})$ and $\mathrm{Cd}(0.03 \pm 0.01 \mu \mathrm{g} / \mathrm{L})$ (Table 4$)$. The order of heavy metals abundance in the untreated wastewater collected prior discharge to the Adventfjorden (sampling point WW) was as follows: $\mathrm{Fe}>\mathrm{Mn}>>\mathrm{Ni} \geq \mathrm{Zn}>\mathrm{Cu} \geq \mathrm{As} \geq \mathrm{V} \geq \mathrm{Co} \geq \mathrm{Cr} \geq \mathrm{Pb}>\mathrm{U}>\mathrm{Cd}$. 
Table 3. Heavy metals concentrations in Longyearbyen's water supply reservoirs, potable water system, wastewater and its marine recipient, Adventfjorden.

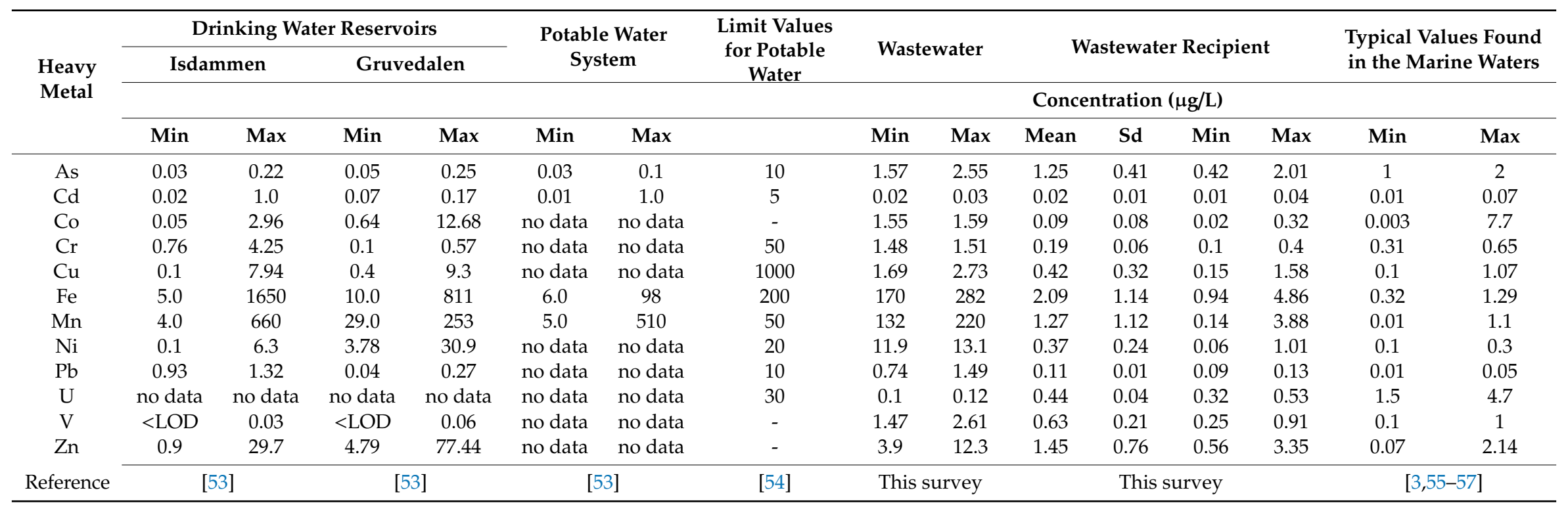


Table 4. Concentrations of heavy metals detected in wastewater from Longyearbyen, polar scientific stations and typically met in the domestic, urban and municipal wastewater.

\begin{tabular}{|c|c|c|c|c|c|c|c|c|c|c|c|c|c|}
\hline \multirow{2}{*}{ Research Area } & \multirow{2}{*}{$\begin{array}{c}\text { Mean } \pm \\
\text { SD/Median }\end{array}$} & \multicolumn{11}{|c|}{ Concentration $(\mu \mathrm{g} / \mathrm{L})$} & \multirow{2}{*}{ Reference } \\
\hline & & $\mathrm{Cu}$ & $\mathrm{Zn}$ & $\mathrm{Pb}$ & $\mathrm{Cr}$ & $\mathrm{Ni}$ & Cd & Mn & $\mathrm{Fe}$ & As & Co & $\mathbf{V}$ & \\
\hline untreated wastewater, & mean & 2.21 & 8.10 & 1.12 & 1.50 & 12.51 & 0.03 & 176 & 226 & 2.06 & 1.57 & 2.04 & \multirow{2}{*}{$\begin{array}{l}\text { This } \\
\text { survey }\end{array}$} \\
\hline Longyearbyen, Svalbard & $\mathrm{SD}$ & 0.74 & 5.88 & 0.53 & 0.02 & 0.83 & 0.01 & 62 & 79 & 0.69 & 0.03 & 0.81 & \\
\hline untreated wastewater, & mean & 564 & 513 & 376 & 32 & 31 & 3.41 & 13.1 & 1646 & & 3.33 & & \multirow{2}{*}{ [8] } \\
\hline McMurdo Antarctic Station & SD & 1073 & 230 & 1169 & 16.8 & 14 & 2.92 & 8.0 & 1205 & & 0.98 & & \\
\hline untreated wastewater, & mean & 870 & 1210 & 37 & 20 & 42 & 4.2 & 176 & & & & & \multirow{2}{*}{ [9] } \\
\hline Davis Station, Antarctica & $\mathrm{SD}$ & 499 & 939 & 8 & 22 & & & 146 & & & & & \\
\hline $\begin{array}{l}\text { Untreated wastewater, Henryk } \\
\text { Arctowski Polish Antarctic Station }\end{array}$ & mean & 4.27 & 37.3 & 0.48 & 4.44 & 23.30 & 0.45 & 28.9 & 428 & \multicolumn{2}{|r|}{1.68} & & {$[58]$} \\
\hline $\begin{array}{l}\text { Domestic wastewater, } \\
\text { residential area, Stockholm }\end{array}$ & mean & 78 & 150 & 3.6 & 4 & 6.2 & 0.23 & & & & & & [26] \\
\hline $\begin{array}{l}\text { Domestic wastewater, } \\
\text { Ostrava, Czech Republic }\end{array}$ & median & 19.5 & 167 & 5.5 & 2.546 & 3.5 & 1.0 & 77.0 & 872 & 0.6 & & & [25] \\
\hline $\begin{array}{l}\text { Wastewater influent to WWTP } \\
\text { Kravare, Czech Republic }\end{array}$ & median & 21.3 & 181 & 5.0 & 2.761 & 4.0 & 1.0 & 69.0 & 963 & 0.5 & & & \\
\hline $\begin{array}{c}\text { Urban wastewater, inflow to WWTP } \\
\text { Ostrava, Czech Republic }\end{array}$ & mean & 35.0 & 230.0 & 17.25 & 12.65 & 18.0 & 0.8 & 452 & 4785 & 1.4 & & & \\
\hline \multirow{2}{*}{$\begin{array}{l}\text { Domestic wastewater, constructed } \\
\text { wetland influent, Zemst, Belgium }\end{array}$} & mean & 7 & 36 & 2 & 1 & 3 & 0.1 & 33 & 45 & & & & \multirow{4}{*}{ [59] } \\
\hline & SD & 9 & 28 & 1 & 0 & 1 & 0.0 & 8 & 19 & & & & \\
\hline \multirow{2}{*}{$\begin{array}{l}\text { Treated wastewater, constructed } \\
\text { wetland efluent, Zemst, Belgium }\end{array}$} & mean & 3 & 26 & 2 & 1 & 3 & 0.1 & 227 & 28 & & & & \\
\hline & $\mathrm{SD}$ & 1 & 21 & 0 & 0 & 1 & 0.1 & 46 & 8 & & & & \\
\hline \multirow{2}{*}{$\begin{array}{l}\text { Raw municipal wastewater, } \\
\text { Thessaloniki, Greece }\end{array}$} & mean & 79 & 470 & 39 & 40 & 770 & 3.3 & 67 & 480 & & & & \multirow{2}{*}{ [60] } \\
\hline & SD & 35 & 140 & 9.4 & 12 & 200 & 1.1 & 12 & 87 & & & & \\
\hline \multirow{2}{*}{$\begin{array}{c}\text { Raw municipal wastewater, } \\
\text { WWTP Gdańsk }\end{array}$} & mean & 125.38 & 439 & 62.58 & & & 20.59 & & & & & & \multirow{2}{*}{ [61] } \\
\hline & SD & 56.17 & 141 & 27.38 & & & 14.05 & & & & & & \\
\hline \multirow{2}{*}{$\begin{array}{c}\text { Raw municipal wastewater, } \\
\text { WWTP Gdańsk }\end{array}$} & mean & 93 & 300 & 16.00 & 20.60 & 13 & 0.50 & & & 4.00 & & 6.00 & \multirow{2}{*}{ [62] } \\
\hline & SD & 30 & 60 & 12.00 & 16.90 & 7 & 0.30 & & & 5.00 & & 5.00 & \\
\hline
\end{tabular}


The concentrations of heavy metals in Adventfjorden investigated in this study followed the general order: $\mathrm{Fe} \geq \mathrm{Zn} \geq \mathrm{Mn} \geq \mathrm{As} \geq \mathrm{V} \geq \mathrm{U} \geq \mathrm{Cu} \geq \mathrm{Ni} \geq \mathrm{Cr} \geq \mathrm{Pb}>\mathrm{Co}>\mathrm{Cd}$, which only to some extent follows the order represented by wastewater presented above. Moreover, in this study, the differences in heavy metals concentrations in the marine water were not as pronounced as in the wastewater. None of the metals in the recipient exceeded concentration of $5 \mu \mathrm{g} / \mathrm{L}$ (Figure 2). In the summer season, $\mathrm{Pb}$ was below detection limit $(<0.10 \mu \mathrm{g} / \mathrm{L})$. The concentrations of cobalt, nickel, cadmium and iron in summer season were the highest at the Adventelva outflow (sampling point $\mathrm{A}$ ). The concentrations of vanadium in October were higher than in July and bottom samples presented higher values than surface water samples. On the contrary, manganese concentrations were on average higher in surface than bottom water samples and were the highest for surface samples in July. A similar relation with the depth was noted for $\mathrm{Ni}, \mathrm{Co}, \mathrm{Fe}$ and $\mathrm{Zn}$. Fe levels also increase near the river outlets (points $\mathrm{L}$ and A, see Figure 2), in contrast to As. Arsenic presents higher concentrations in the bottom water samples, which is more pronounced in July.

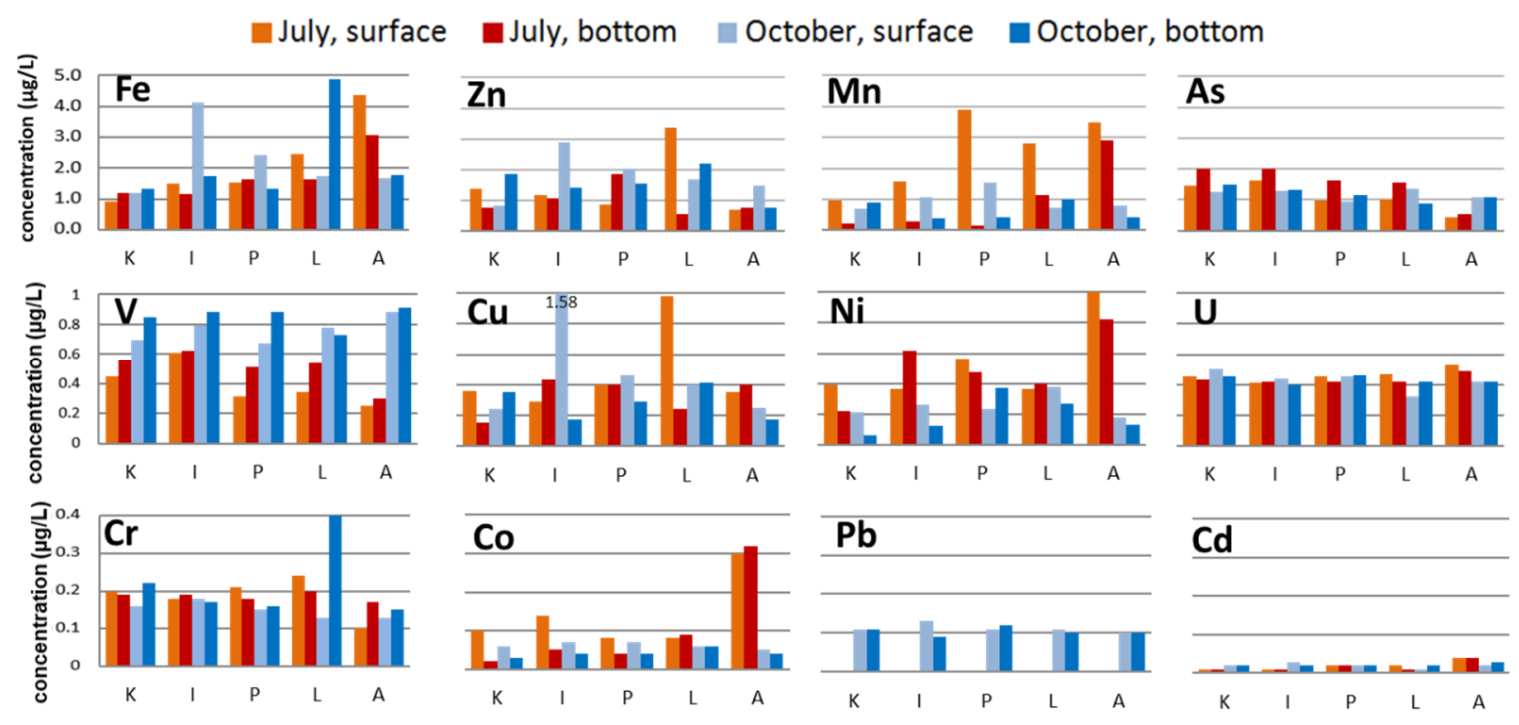

Figure 2. Concentrations of heavy metals in marine waters of Adventfjorden. The labels on the $x$ axis refer to the name of the sampling stations (K, I, P, L, A).

The difference between heavy metals concentration in wastewater and recipient was the highest for $\mathrm{Mn}$ and $\mathrm{Fe}$ (over 100 times higher concentration in wastewater than in marine waters), Ni and Co (33 times and 18 times higher, respectively). The smallest difference between sewage and recipient was noted for As and Cd (mean value in wastewater was around $150 \%$ of the mean concentration in marine waters). $U$ concentrations were on average higher in Adventfjorden than in the wastewater.

\subsection{TSS, TOC and Correlations with Heavy Metals}

In July, TSS concentration in the recipient reached values much higher than in October (up to $835.11 \mathrm{mg} / \mathrm{L}$ versus $11.40 \mathrm{mg} / \mathrm{L}$, respectively). The highest values were recorded in July at the Adventelva outlet (point A), followed by points $\mathrm{L}$ and $\mathrm{P}$ in the inner Adventfiorden basin $(53.60-62.2 \mathrm{mg} / \mathrm{L}$ in the surface water samples and $16.1-29.5 \mathrm{mg} / \mathrm{L}$ in the bottom layer). The lowest TSS was noted for outer stations K and I (2.47-10.8 mg/L). In October, when the river discharge into the fiord decreases, TSS concentration did not exceed $12 \mathrm{mg} / \mathrm{L}$ at all stations (Figure 3). 

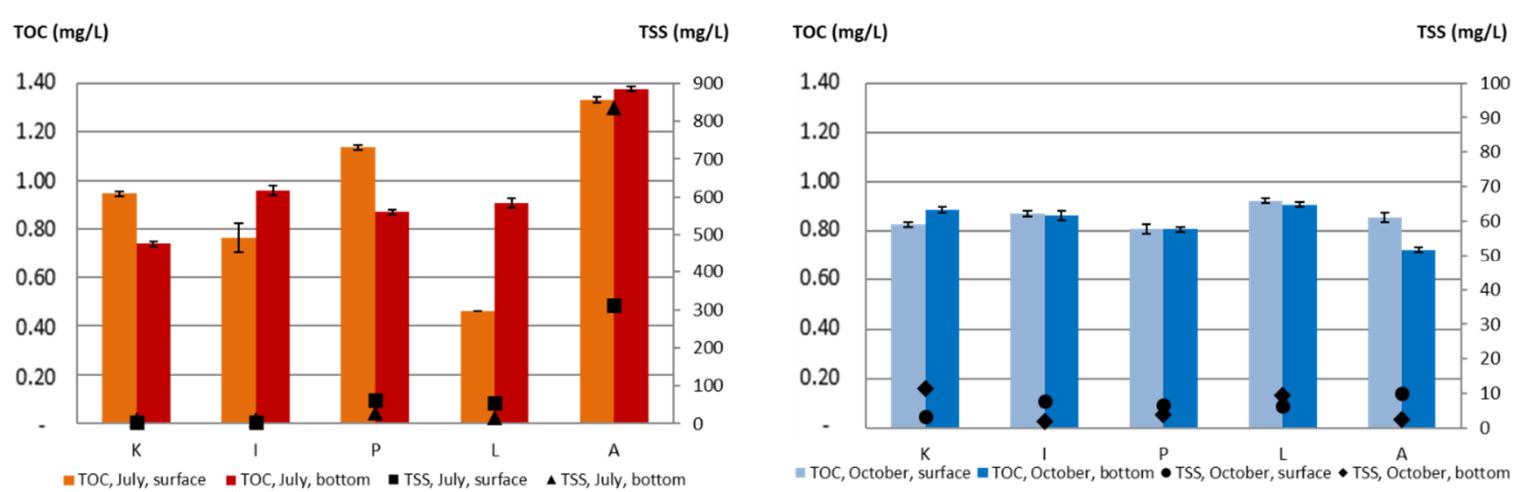

Figure 3. Total organic carbon and suspended solids concentrations in the recipient in July (left) and October (right). The bars refer to TOC values, the black symbols to TSS. Note different scales for TSS. The labels on the $x$ axis refer to the name of the sampling stations (K, I, P, L, A).

Total organic carbon (TOC) concentrations were around 40 times higher in wastewater samples (sampling point WW), than in the recipient (mean of $39 \mathrm{mg} / \mathrm{L}$ in wastewater versus mean $0.9 \mathrm{mg} / \mathrm{L}$ in marine waters). TOC values in Adventfjorden oscillated from $0.85 \pm 0.06 \mathrm{mg} / \mathrm{L}$ in October to $0.95 \pm 0.28 \mathrm{mg} / \mathrm{L}$ in July (Figure 3 ) and the highest values were found and wastewater discharge pipe and at the mouth of Adventelva river in July (sampling points $\mathrm{P}$ and A, respectively). In October, no significant correlation was found between TSS and TOC, even though the correlations in July and for the whole set of data were strong $(0.69 \mathrm{mg} / \mathrm{L}$ and $0.71 \mathrm{mg} / \mathrm{L}$, respectively, see Table 5). 
Table 5. Values of Pearson correlation coefficient ( $r$ ) for total concentrations of investigated elements (selected metals nonmetals and total organic carbon concentration). Strong and very strong correlations $(0.6<|\mathrm{r}| \leq 1)$ are given in bold. Grey background emphasize very strong correlations $(0.8<|\mathrm{r}| \leq 1)$. Values of Pearson's correlation coefficients in the range $(0.6<|\mathrm{r}| \leq 1)$ are statistically significant at $\mathrm{p}<0.05$.

\begin{tabular}{|c|c|c|c|c|c|c|c|c|c|c|c|c|c|c|}
\hline $\begin{array}{l}\text { Analyzed } \\
\text { Parameter }\end{array}$ & $\mathbf{V}$ & $\mathrm{Cr}$ & Mn & $\mathrm{Fe}$ & Co & $\mathrm{Ni}$ & $\mathrm{Cu}$ & $\mathrm{Zn}$ & As & $\mathrm{Cd}$ & $\mathrm{Pb}$ & $\mathbf{U}$ & TOC & TSS \\
\hline $\mathrm{V}$ & 1 & & & & & & & & & & & & & \\
\hline $\mathrm{Cr}$ & 0.832 & 1.000 & & & & & & & & & & & & \\
\hline $\mathrm{Mn}$ & 0.896 & 0.958 & 1.000 & & & & & & & & & & & \\
\hline $\mathrm{Fe}$ & 0.721 & 0.955 & 0.870 & 1.000 & & & & & & & & & & \\
\hline Co & 0.774 & 0.968 & 0.950 & 0.957 & 1.000 & & & & & & & & & \\
\hline $\mathrm{Ni}$ & 0.835 & 0.984 & 0.977 & 0.952 & 0.990 & 1.000 & & & & & & & & \\
\hline $\mathrm{Cu}$ & 0.592 & 0.833 & 0.744 & 0.876 & 0.827 & 0.820 & 1.000 & & & & & & & \\
\hline $\mathrm{Zn}$ & 0.504 & 0.801 & 0.638 & 0.907 & 0.779 & 0.764 & 0.908 & 1.000 & & & & & & \\
\hline As & 0.392 & 0.487 & 0.384 & 0.545 & 0.399 & 0.453 & 0.443 & 0.538 & 1.000 & & & & & \\
\hline $\mathrm{Cd}$ & 0.006 & 0.173 & 0.145 & 0.273 & 0.311 & 0.218 & 0.349 & 0.296 & -0.430 & 1.000 & & & & \\
\hline $\mathrm{Pb}$ & 0.706 & 0.913 & 0.807 & 0.985 & 0.907 & 0.901 & 0.873 & 0.936 & 0.544 & 0.296 & 1.000 & & & \\
\hline $\mathrm{U}$ & -0.841 & -0.914 & -0.876 & -0.897 & -0.870 & -0.905 & -0.758 & -0.767 & -0.622 & 0.021 & -0.878 & 1.000 & & \\
\hline TOC & 0.824 & 0.988 & 0.958 & 0.975 & 0.987 & 0.995 & 0.841 & 0.813 & 0.494 & 0.223 & 0.937 & -0.919 & 1.000 & \\
\hline TSS & -0.536 & -0.154 & 0.541 & 0.361 & 0.862 & 0.669 & -0.006 & -0.270 & -0.565 & 0.671 & -0.334 & 0.457 & 0.707 & 1.000 \\
\hline
\end{tabular}




\section{Discussion}

\subsection{Heavy Metals in the Wastewater}

Wastewater generated in Longyearbyen contained higher heavy metals concentrations than the Advenfjorden, thus, it can be considered as a point source of pollution. Apart from nickel and manganese, heavy metals concentrations in wastewater from Longyearbyen were lower than in typical municipal wastewater $[25,26,59,61]$ and wastewater generated at the Antarctic stations $[8,9,58]$, see Table 4. The higher concentrations in the municipal wastewater should be attributed to the industrial contribution, while at Antarctic stations the main explanation may be the lack of dilution, as those settlements usually operate at a minimum water consumption, with a less efficient potable water supply system than in Longyearbyen.

The order of heavy metals abundance in the untreated wastewater $(\mathrm{Fe}>\mathrm{Mn}>>\mathrm{Ni} \geq \mathrm{Zn}>\mathrm{Cu} \geq$ $\mathrm{As} \geq \mathrm{V} \geq \mathrm{Co} \geq \mathrm{Cr} \geq \mathrm{Pb}>\mathrm{U}>\mathrm{Cd}$ ) is mostly in agreement with the relative abundance reported by Chipasa [61] and Karvelas [60] in municipal wastewater, apart from Ni and Mn abundances, which are higher in case of Longyearbyen wastewater.

In domestic wastewater, trace elements can originate from toilet paper, detergents, medicines cosmetics and other personal care products [25-27,29], see Table 1. Moreover, food leftovers can contain trace elements-note that in Longyearbyen, they are milled in sinks and directed to the sewer. Sörme and Laderkvist [26] indicated household emissions, such as food and artistic paints, as the second largest contributor of $\mathrm{Cd}$ in the wastewater. It has been estimated that approximately 100 tonnes of food is discharged to the fjord every year. Food waste constitutes about $0.4 \mathrm{~m}^{3}$ daily, which can be of a significant importance with regard to local organic load and the supply of certain heavy metals [63].

Plumbing material, especially copper piping, which is also used in the Longyearbyen water supply system, was pointed out by Comber and Gunn [27] and Sörme and Lagerkvist [26] as an additional source of trace elements (mainly $\mathrm{Cu}, \mathrm{Pb}$ and $\mathrm{Zn}$ ) in wastewater. Taps, heat exchangers in housing, iron valves in the pumping stations and slightly acidic $\mathrm{pH}$ may also contribute to heavy metals load in Longyerbyen water and then wastewater. Indirectly, it is confirmed by a large corrosion on the metal pipes that has been reported in town (Kjersti Olsen Ingerø, Longyearbyen Lokalstyre, pers. comm.).

In Longyearbyen, the drinking water system is supplied by two meltwater and rain fed reservoirs in Gruvedalen and Isdammen watershed. Nowak and Hodson [64] indicated the influence of acid mine drainage on the quality of drinking water sources, especially at the beginning and end of the summer. In spring, heavy metals are delivered by melting snowpack and can be leached from the underlying mine waste rock. At the end of the summer, the surface runoff is lower and the rock-water contact is prolonged, also resulting in higher trace elements concentrations. Heavy rainfalls during the year may deliver contamination from the hillslopes, but also dilute them. In Longyearbyen's drinking water reservoirs (Isdammen and Gruvedalen) concentrations of $\mathrm{Mn}, \mathrm{Fe}, \mathrm{Cr}, \mathrm{Co}, \mathrm{Cd}, \mathrm{Cu}, \mathrm{Zn}$ and Ni were noted to be higher than those in the wastewater (Table 3). For example, in Isdammen reservoir over 70\% of the analyses in years 2005-2017 revealed manganese concentrations higher than allowed for drinking water [53], indicating the need of pre-treatment. In this case, drinking water may contribute to a significant share of heavy metals in the wastewater, especially $\mathrm{Mn}, \mathrm{Fe}, \mathrm{Cr}, \mathrm{Co}, \mathrm{Cd}, \mathrm{Cu}, \mathrm{Zn}, \mathrm{Ni}, \mathrm{Pb}$ (Table 3).

\subsection{Heavy Metals in the Adventfjorden}

In the summer, the highest concentrations of $\mathrm{Co}, \mathrm{Ni}, \mathrm{Cd}$ and Fe were noted at the Adventelva outflow (sampling point A), which suggests the impact of the river. This is supported by Bazzano et al. [65], who found that natural input from the glaciers is the major source for Co, Fe and $\mathrm{V}$ in another fjord system in Svalbard, Kongsfjorden. In case of vanadium, however, this trend in our data cannot be seen. This suggests that other factors rather than river discharge can play a more significant role in the distribution of vanadium concentrations. Manganese and cobalt seem to depend on the sampling depth in the fiord, but also reveal higher concentrations at the river mouth 
in the summer (similarly to Fe), which suggests the contribution of freshwater to discharge these metals into the fiord. Additionally, the physical mixing of the fresh water with seawater masses influences the concentration of heavy metals, which was confirmed for dissolved arsenic in estuarine waters [66-70]. The increase of As concentrations with the increasing salinity (freshwater versus seawater) observed in our dataset was also recorded in Krka Estuary [71]. The lowest As values in our data was observed at the stations with the greatest freshwater influence in the period when river discharge is the highest. Higher concentrations in the bottom water masses are especially visible in data from the summer (Figure 2) when the stratification in the fiord is the strongest. Separation of water masses slows down mixing and therefore, restricts vertical migration of pollutants that are not bound to solid particles and therefore, are not prone to settling. According to Bazzano et al. [65], $\mathrm{Cr}, \mathrm{Cu}, \mathrm{Mn}$, $\mathrm{Ni}, \mathrm{Pb}$ and $\mathrm{Zn}$ in the Arctic fiord were mainly introduced with the inflow of Atlantic waters. This may be reflected by the higher concentrations of $\mathrm{Cr}, \mathrm{Cu}$ and $\mathrm{Zn}$ observed at Longyearelva mouth (sampling point L), which is located on the way of general water current in Adventfiorden (see Figure 1).

The sources of heavy metals in the fiord, apart from wastewater discharge, can also be associated with other human activities, which makes tracking of pollution origin in the fiord a complex task. For instance, allochthonous sources of heavy metals Longyearbyen may include ships and airplanes, which may contribute to heavy metals emission into the environment. In addition, old waste dumping sites have been frequently mentioned as a heavy metals pollution source in the vicinity of human settlements in polar regions [8]. In the case of Longyearbyen, the dumpsite at the seashore was closed in 1990 [63] and moved further from the fiord; however, the risk of leaching heavy metals from the old dumping site or coal mining constructions remnants still exists. In the case of $\mathrm{Cd}$, however, there is little evidence that its concentration in the marine waters has been impacted by human activities [3,72], which is in contrary to nickel. Its relatively high concentration in biota around Longyearbyen has been attributed to the mining activity in the area [35]. As mentioned above, some contaminants could be potentially delivered into Adventfjorden via river discharge.

\subsection{Correlations with TSS and TOC}

Total suspended solids values correlated with the Adventelva and Longyearelva inflow, as they introduce a large amount of coarse silt. This relation has also been noted in other studies in the area $[50,73]$. In contrary to the wastewater, TSS originated from rivers is mainly in mineral form [Kalinowska, unpublished data]. This may be of importance, as heavy metals usually show correlations with the organic matter content [74]. Wastewater is the main contributor of TOC and heavy metals to the recipient. Suspended solids, which are mainly of the glacial river origin, do not contribute strongly to the heavy metals input to the fiord. The influence of the surface runoff or remobilization of heavy metals from the sediments has not, however, been studied.

\section{Conclusions}

We found that untreated wastewater discharged by Longyearbyen to the nearby Adventfjorden delivers heavy metals in concentrations similar or lower to typical domestic wastewater, also those from polar scientific stations. Despite the low pollutants concentration, wastewater can be considered a local pollution point source, as it contains slightly higher concentrations of heavy metals that the waters of its marine recipient.

No spatial or seasonal pattern in distribution in the recipient was found for all the elements analyzed. Nevertheless, some patterns, specific for individual metals, were noted: concentrations of manganese, cobalt, nickel, cadmium, iron and arsenic seem to be impacted by river discharge into the fiord, which is the strongest during the summer. Rivers, however, can be influenced by the vicinity of former or still existing mining sites. Chromium, copper and zinc concentrations can partly depend on Atlantic waters inflow into the Advenfjorden. Taking into account the relatively small volume of wastewater introduced to the Adventfjorden-Isfjorden system and dynamic exchange with water outside the fiord, we conclude that the wastewater is diluted and the concentrations of heavy metals in 
Adventfjorden are influenced by other factors, including water masses dynamics in the fiord, oceanic currents, river inflow and mixing.

Nonetheless, further wastewater monitoring and its impact on the fiord is recommended due to the growing number of Longyearbyen's visitors and inhabitants, resulting in the increase of wastewater volume in the following years. Special attention should also be given to substances of emerging concern, such as pharmaceuticals and personal care products (PPCP), together with antibiotic resistant bacteria (ARBs) and genes (ARGs). Data collected throughout the years may serve as a basis for the local authorities to undertake the appropriate research, monitoring as well as proper prevention and mitigation action.

Author Contributions: Conceptualization, A.K. and A.Ł.; methodology, S.C., M.K., M.S. and W.A.; software, K.J. and W.A.; validation, S.C., M.K. and M.S.; formal analysis, A.Ł. and Ż.P.; investigation, A.K., M.S., S.C. and M.K.; data curation, A.K., K.J. and W.A.; writing-original draft preparation, A.K. and A.N.; writing-review and editing, A.K., A.Ł. and Ż.P.; visualization, K.J.; supervision, A.Ł.; project administration, A.K. and A.Ł.; funding acquisition, A.K., A.E. and A.N. All authors have read and agreed to the published version of the manuscript.

Funding: This research was funded by Research Council of Norway and the Norwegian Polar Institute, grant number 282607, Arctic Field Grant.

Acknowledgments: Authors thank the Research Council of Norway for research funding for Arctic Field Grant "Influence of wastewater on the bacterioplankton community and its characteristics in Adventfjorden, Svalbard", RIS-ID: 10924. Authors would also like to express gratitude to Longyearbyen Lokalstyre (Mrs. Kjersti Olsen Ingerø) and University Centre in Svalbard staff - Arctic Biology Department (Anna Vader, Janne Søreide), Arctic Geophysics (Eva Falck, Ylva Ericson), Arctic Geology (Andy Hodson) and Logistics Department for help during the fieldwork campaign and data analysis.

Conflicts of Interest: The authors declare no conflict of interest. The funders had no role in the design of the study; in the collection, analyses, or interpretation of data; in the writing of the manuscript, or in the decision to publish the results.

\section{References}

1. Levy, S.B.; Marshall, B. Antibacterial resistance worldwide: Causes, challenges and responses. Nat. Med. 2004, 10, S122-S129. [CrossRef] [PubMed]

2. Statistics Norway. This Is Svalbard 2016: What the Figures Say; Statistics Norway: Oslo, Norway, 2016.

3. Muir, D.C.G.; Wagemann, R.; Hargrave, B.T.; Thomas, D.J.; Peakall, D.B.; Norstrom, R.J. Arctic marine ecosystem contamination. Sci. Total Environ. 1992, 122, 75-134. [CrossRef]

4. McConnell, M. Abundance of Antibiotic Resistance Genes in Two Municipal Wastewater Treatment Plants and Receiving Water in Atlantic Canada. Master's Thesis, Dalhousie University, Halifax, NS, Canada, March 2017. Available online: https://dalspace.library.dal.ca/bitstream/handle/10222/72949/McConnell-MandyMASc-ENVE-March-2017.pdf?sequence=1 (accessed on 10 November 2019).

5. Nakahara, H.; Ishikawa, T.; Sarai, Y.; Kondo, I. Frequency of heavy-metal resistance in bacteria from inpatients in Japan. Nature 1977, 266, 165-167. [CrossRef] [PubMed]

6. Rizzo, L.; Manaia, C.; Merlin, C.; Schwartz, T.; Dagot, C.; Ploy, M.C.; Michael, I.; Fatta-Kassinos, D. Urban wastewater treatment plants as hotspots for antibiotic resistant bacteria and genes spread into the environment: A review. Sci. Total Environ. 2013, 447, 345-360. [CrossRef] [PubMed]

7. Sandrin, T.R.; Maier, R.M. Impact of metals on the biodegradation of organic pollutants. Environ. Health Perspect. 2003, 111, 1093-1101. [CrossRef] [PubMed]

8. Crockett, A.B. Water and wastewater quality monitoring, McMurdo Station, Antarctica. Environ. Monit. Assess. 1997, 47, 39-57. [CrossRef]

9. Stark, J.S.; Smith, J.; King, C.K.; Lindsay, M.; Stark, S.; Palmer, A.S.; Snape, I.; Bridgen, P.; Riddle, M. Physical, chemical, biological and ecotoxicological properties of wastewater discharged from Davis Station, Antarctica. Cold Reg. Sci. Technol. 2015, 113, 52-62. [CrossRef]

10. Stark, J.S.; Bridgen, P.; Dunshea, G.; Galton-Fenzi, B.; Hunter, J.; Johnstone, G.; King, C.; Leeming, R.; Palmer, A.; Smith, J.; et al. Dispersal and dilution of wastewater from an ocean outfall at Davis Station, Antarctica, and resulting environmental contamination. Chemosphere 2016, 152, 142-157. [CrossRef]

11. McConnell, J.R.; Edwards, R. Coal burning leaves toxic heavy metal legacy in the Arctic. Proc. Natl. Acad. Sci. USA 2008, 105, 12140-12144. [CrossRef] 
12. Allen-Gil, S.M.; Ford, J.; Lasorsa, B.K.; Monetti, M.; Vlasova, T.; Landers, D.H. Heavy metal contamination in the Taimyr Peninsula, Siberian Arctic. Sci. Total Environ. 2003, 301, 119-138. [CrossRef]

13. Halbach, K.; Mikkelsen, Ø.; Berg, T.; Steinnes, E. The presence of mercury and other trace metals in surface soils in the Norwegian Arctic. Chemosphere 2017, 188, 567-574. [CrossRef] [PubMed]

14. AMAP. AMAP Assessment 2002: Heavy Metals in the Arctic; Arctic Monitoring and Assessment Programme (AMAP): Tromsø, Norway, 2005.

15. Sun, Q.; Chu, G.; Liu, J.; Gao, D. A 150-year Record of Heavy Metals in the Varved Sediments of Lake Bolterskardet, Svalbard. Arct. Antarct. Alp. Res. 2006, 38, 436-445. [CrossRef]

16. Drbal, K.; Elster, J.; Komárek, J. Heavy metals in water, ice and biological material from Spitsbergen, Svalbard. Polar Res. 1992, 11, 99-101. [CrossRef]

17. Matoba, S.; Motoyama, H.; Narita, H.; Watanabe, O. Anthropogenic trace metals in an ice core at Vestfonna, Svalbard, Norway.pdf. Chin. J. Polar Sci. 2003, 14, 41-47.

18. Łokas, E.; Zaborska, A.; Kolicka, M.; Różycki, M.; Zawierucha, K. Accumulation of atmospheric radionuclides and heavy metals in cryoconite holes on an Arctic glacier. Chemosphere 2016, 160, 162-172. [CrossRef]

19. Węgrzyn, M.; Wietrzyk, P.; Lisowska, M.; Klimek, B.; Nicia, P. What influences heavy metals accumulation in arctic lichen Cetrariella delisei in Svalbard? Polar Sci. 2016, 10, 532-540. [CrossRef]

20. Karl, H.; Kammann, U.; Aust, M.O.; Manthey-Karl, M.; Lüth, A.; Kanisch, G. Large scale distribution of dioxins, PCBs, heavy metals, PAH-metabolites and radionuclides in cod (Gadus morhua) from the North Atlantic and its adjacent seas. Chemosphere 2016, 149, 294-303. [CrossRef]

21. Zauke, G.P.; Savinov, V.M.; Ritterhoff, J.; Savinova, T. Heavy metals in fish from the Barents Sea (summer 1994). Sci. Total Environ. 1999, 227, 161-173. [CrossRef]

22. Norheim, G.; Skaare, J.U.; Wiig, Ø. Some heavy metals, essential elements, and chlorinated hydrocarbons in polar bear (Ursus maritimus) at Svalbard. Environ. Pollut. 1992, 77, 51-57. [CrossRef]

23. Fant, M.L.; Nyman, M.; Helle, E.; Rudbäck, E. Mercury, cadmium, lead and selenium in ringed seals (Phoca hispida) from the Baltic Sea and from Svalbard. Environ. Pollut. 2001, 111, 493-501. [CrossRef]

24. Jæger, I.; Hop, H.; Gabrielsen, G.W. Biomagnification of mercury in selected species from an Arctic marine food web in Svalbard. Sci. Total Environ. 2009, 407, 4744-4751. [CrossRef] [PubMed]

25. Drozdova, J.; Raclavska, H.; Raclavsky, K.; Skrobankova, H. Heavy metals in domestic wastewater with respect to urban population in Ostrava, Czech Republic. Water Environ. J. 2019, 33, 77-85. [CrossRef]

26. Sörme, L.; Lagerkvist, R. Sources of heavy metals in urban wastewater in Stockholm. Sci. Total Environ. 2002, 298, 131-145. [CrossRef]

27. Comber, S.D.W.; Gunn, A.M. Heavy metals entering sewage-treatment works from domestic sources. Water Environ. J. 1996, 10, 137-142. [CrossRef]

28. Thévenot, D.R.; Moilleron, R.; Lestel, L.; Gromaire, M.C.; Rocher, V.; Cambier, P.; Bonté, P.; Colin, J.L.; de Pontevès, C.; Meybeck, M. Critical budget of metal sources and pathways in the Seine River basin (1994-2003) for $\mathrm{Cd}, \mathrm{Cr}, \mathrm{Cu}, \mathrm{Hg}, \mathrm{Ni}, \mathrm{Pb}$ and Zn. Sci. Total Environ. 2007, 375, 180-203. [CrossRef] [PubMed]

29. Moriyama, K.; Mori, T.; Arayashiki, H.; Saitot, H.; Chino, M. The amount of heavy metals derived from domestic wastewater. Water Pollut. Res. Control. Bright. 1988, 1913-1916. [CrossRef]

30. Meinzinger, F; Oldenburg, M. Characteristics of source-separated household wastewater flows: A statistical assessment. Water Sci. Technol. 2009, 59, 1785-1791. [CrossRef]

31. Khatib, R.E.; Lartiges, B.S.; Samrani, A.E.; Faure, P.; Houhou, J.; Ghanbaja, J. Speciation of organic matter and heavy metals in urban wastewaters from an emerging Country. Water Air Soil Pollut. 2012, 223, 4695-4708. [CrossRef]

32. Aonghusa, C.N.; Gray, N.F. Laundry detergents as a source of heavy metals in Irish domestic wastewater. J. Environ. Sci. Health Part A 2002, 37, 1-6. [CrossRef]

33. Eriksson, E.; Donner, E. Metals in greywater: Sources, presence and removal efficiencies. Desalination 2009, 248, 271-278. [CrossRef]

34. Jenkins, D.; Russell, L.L. Heavy metals contribution of household washing products to municipal wastewater. Water Environ. Res. 1994, 66, 805-813. [CrossRef]

35. Kłos, A.; Ziembik, Z.; Rajfur, M.; Dołhańczuk-Sródka, A.; Bochenek, Z.; Bjerke, J.W.; Tømmervik, H.; Zagajewski, B.; Ziółkowski, D.; Jerz, D.; et al. The Origin of Heavy Metals and Radionuclides Accumulated in the Soil and Biota Samples Collected in Svalbard, Near Longyearbyen. Ecol. Chem. Eng. S 2017, 24, 223-228. [CrossRef] 
36. Granberg, M.E.; Ask, A.; Gabrielsen, G.W. Local Contamination in Svalbard-Overview and Suggestions for Remediation Actions; Norsk Polarinstitutt: Tromsø, Norway, 2017.

37. Cheng, S. Heavy metal pollution in China: Origin, pattern and control. Environ. Sci. Pollut. Res. 2003, 10, 192-198. [CrossRef] [PubMed]

38. Weidenhamer, J.D.; Kobunski, P.A.; Kuepouo, G.; Corbin, R.W.; Gottesfeld, P. Lead exposure from aluminum cookware in Cameroon. Sci. Total Environ. 2014, 496, 339-347. [CrossRef]

39. Weidenhamer, J.D.; Fitzpatrick, M.P.; Biro, A.M.; Kobunski, P.A.; Hudson, M.R.; Corbin, R.W.; Gottesfeld, P. Metal exposures from aluminum cookware: An unrecognized public health risk in developing countries. Sci. Total Environ. 2017, 579, 805-813. [CrossRef]

40. Juhaiman, L.A. Estimating Aluminum Leaching from Aluminum Cookware in Different Vegetable Extracts. Int. J. Electrochem. Sci. 2012, 7, 7283-7294.

41. Bergkvist, C.; Kippler, M.; Hamadani, J.D.; Grandér, M.; Tofail, F.; Berglund, M.; Vahter, M. Assessment of early-life lead exposure in rural Bangladesh. Environ. Res. 2010, 110, 718-724. [CrossRef]

42. Mohammad, F.S.; Al Zubaidy, E.A.H.; Bassioni, G. Effect of Aluminum Leaching Process of Cooking Wares on Food. Int. J. Electrochem. Sci. 2011, 6, 222-230.

43. Al Zubaidy, E.A.H.; Mohammad, F.S.; Bassioni, G. Effect of pH, Salinity and Temperature on Aluminum Cookware Leaching During Food Preparation. Int. J. Electrochem. Sci. 2011, 6, 6424-6441.

44. Houhou, J.; Lartiges, B.S.; Montarges-Pelletier, E.; Sieliechi, J.; Ghanbaja, J.; Kohler, A. Sources, nature, and fate of heavy metal-bearing particles in the sewer system. Sci. Total Environ. 2009, 407, 6052-6062. [CrossRef]

45. Khan, S.; Rehman, S.; Zeb Khan, A.; Amjad Khan, M.; Tahir Shah, M. Soil and vegetables enrichment with heavy metals from geological sources in Gilgit, northern Pakistan. Ecotoxicol. Environ. Saf. 2010, 73, 1820-1827. [CrossRef] [PubMed]

46. Chino, M.; Moriyama, K.; Saito, H.; Morn, T. The amount of heavy metals derived from domestic sources in Japan. Water Air Soil Pollut. 1991, 57, 829-837. [CrossRef]

47. Gimeno-García, E.; Andreu, V.; Boluda, R. Heavy metals incidence in the application of inorganic fertilizers and pesticides to rice farming soils. Environ. Pollut. 1996, 92, 19-25. [CrossRef]

48. Tjandraatmadja, G.; Diaper, C. Sources of Critical Contaminants in Domestic Wastewater: A Literature Review; CSIRO: Canberra, Australia, 2006.

49. Pawłowska, J.; Włodarska-Kowalczuk, M.; Zajączkowski, M.; Nygård, H.; Berge, J. Seasonal variability of meio- and macrobenthic standing stocks and diversity in an Arctic fjord (Adventfjorden, Spitsbergen). Polar Biol. 2011, 34, 833-845. [CrossRef]

50. Zajaczkowski, M.; Włodarska-Kowalczuk, M. Dynamic sedimentary environments of an Arctic glacier-fed river estuary (Adventfjorden, Svalbard). I. Flux, deposition, and sediment dynamics. Estuar. Coast. Shelf Sci. 2007, 74, 285-296. [CrossRef]

51. Szyma, N.; Paw, J.; Kujawa, A.; Łącka, M.; Zajączkowski, M. ScienceDirect Impact of shelf-transformed waters (STW) on foraminiferal assemblages in the outwash and glacial fjords of Adventfjorden and Hornsund, Svalbard. Oceanologia 2017, 59, 525-540. [CrossRef]

52. APHA. Standard Methods for the Examination of Water and Wastewater; American Public Health Association (APHA): Washington, DC, USA, 2005.

53. Olsen Ingerø, K. Longyearbyen Lokalstyre Annual Reports; Lokalstyre: Longyearbyen, Norway, $2002-2017$.

54. Environmental Protection Agency. 2018 Edition of the Drinking Water Standards and Health Advisories Tables; EPA: Washington, DC, USA, 2018.

55. Glabonjat, R.A.; Raber, G.; Van Mooy, B.A.S.; Francesconi, K.A. Arsenobetaine in Seawater: Depth Profiles from Selected Sites in the North Atlantic. Environ. Sci. Technol. 2018, 52, 522-530. [CrossRef]

56. Moore, R.M. Oceanographic distributions of zinc, cadmium, copper and aluminium in waters of the central arctic. Geochim. Cosmochim. Acta 1981, 45, 2475-2482. [CrossRef]

57. Campbell, J.A.; Yeats, P.A. The distribution of manganese, iron, nickel, copper and cadmium in the waters of Baffin Bay and the Canadian Arctic Archipelago. Deep Sea Res. Part. B Oceanogr. Lit. Rev. 1982, $29,764$.

58. Szopińska, M.; Łuczkiewicz, A.; Jankowska, K.; Fudala-Książek, S.; Potapowicz, J.; Kalinowska, A.; Bialik, R.J.; Chmiel, S.; Polkowska, Ż. Tracking of selected macro and micropollution in Admiralty Bay after wastewater discharge: Case study of Arctowski Station. Manuscr. Revis. 2020. Unpublished work. 
59. Lesage, E.; Rousseau, D.P.L.; Meers, E.; Tack, F.M.G.; De Pauw, N. Accumulation of metals in a horizontal subsurface flow constructed wetland treating domestic wastewater in Flanders, Belgium. Sci. Total Environ. 2007, 380, 102-115. [CrossRef]

60. Karvelas, M.; Katsoyiannis, A.; Samara, C. Occurrence and fate of heavy metals in the wastewater treatment process. Chemosphere 2003, 53, 1201-1210. [CrossRef]

61. Chipasa, K.B. Accumulation and fate of selected heavy metals in a biological wastewater treatment system. Waste Manag. 2003, 23, 135-143. [CrossRef]

62. Gdańsk-Wschód Wastewater Treatment Plant; Gdańsk-Wschód Wastewater Treatment Plant Reports. Unpublished data. 2013-2014.

63. Evenset, A. Adventfjorden Som Resipient for Sanitæravløp og Kvernet matavfall fra Longyearbyen; Akvaplan Niva; Polarmiljøsenteret: Tromsø, Norway, 2017.

64. Nowak, A.; Hodson, A. The Water Supply to Longyearbyen: Understanding the Present System and Future Uncertainties. 2013. Available online: https:/www.researchgate.net/publication/258515564_The_ water_supply_to_Longyearbyen_understanding_the_present_system_and_future_uncertainties (accessed on 15 December 2019).

65. Bazzano, A.; Rivaro, P.; Soggia, F.; Ardini, F.; Grotti, M. Anthropogenic and natural sources of particulate trace elements in the coastal marine environment of Kongsfjorden, Svalbard. Mar. Chem. 2014, 163, $28-35$. [CrossRef]

66. Hasegawa, H. Seasonal Changes in Methylarsenic Distribution in Tosa Bay and Uranouchi Inlet. Appl. Organomet. Chem. 1996, 10, 733-740. [CrossRef]

67. Guo, H.R.; Yu, H.S.; Hu, H.; Monson, R.R. Arsenic in drinking water and skin cancers: Cell-type specificity (Taiwan, R.O.C.). Cancer Causes Control. 2001, 12, 909-916. [CrossRef]

68. Gurzau, E.S.; Gurzau, A.E. Arsenic in drinking water from groundwater in Transylvania, Romania: An overview. In Arsenic Exposure and Health Effects IV; Chappell, W.R., Abernathy, C., Calderon, R.L., Eds.; Elsevier: Oxford, UK, 2001; pp. 181-184.

69. Harvey, C.F.; Swartz, C.H.; Badruzzaman, A.B.M.; Keon-Blute, N.; Yu, W.; Ali, M.A.; Jay, J.; Beckie, R.; Niedan, V.; Brabander, D.; et al. Arsenic mobility and groundwater extraction in Bangladesh. Science 2002, 298, 1602-1606. [CrossRef]

70. Gunduz, O.; Simsek, C.; Hasozbek, A. Arsenic pollution in the groundwater of Simav Plain, Turkey: Its impact on water quality and human health. Water Air Soil Pollut. 2010, 205, 43-62. [CrossRef]

71. Seyler, P.; Martin, J.M. Arsenic and selenium in a pristine river-estuarine system: The Krka (Yugoslavia). Mar. Chem. 1991, 34, 137-151. [CrossRef]

72. Macdonald, R.W.; Barrie, L.A.; Bidleman, T.F.; Diamond, M.L.; Gregor, D.J.; Semkin, R.G.; Strachan, W.M.J.; Li, Y.F.; Wania, F.; Alaee, M.; et al. Contaminants in the Canadian Arctic: 5 years of progress in understanding sources, occurrence and pathways. Sci. Total Environ. 2000, 254, 93-234. [CrossRef]

73. Zajączkowski, M.; Szczuciński, W.; Bojanowski, R. Recent changes in sediment accumulation rates in Adventfjorden, Svalbard. Oceanologia 2004, 46, 2.

74. Reuter, J.H.; Perdue, E.M. Importance of heavy metal-organic matter interactions in natural waters. Geochim. Cosmochim. Acta 1977, 41, 325-334. [CrossRef]

(C) 2020 by the authors. Licensee MDPI, Basel, Switzerland. This article is an open access article distributed under the terms and conditions of the Creative Commons Attribution (CC BY) license (http://creativecommons.org/licenses/by/4.0/). 